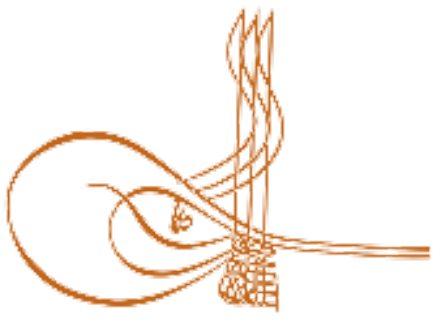

www.turkishstudies.net/education
Turkish Studies - Educational Sciences

eISSN: $2667-5609$

Research Article / Araştırma Makalesi

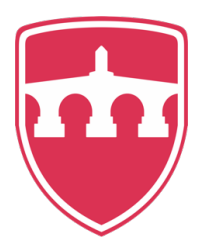

INTERNATIONAL

BALKAN

UNIVERSITY

Sponsored by IBU

\title{
Ortaokul Öğrencilerinin Çevre Mühendisliği Bilgi Düzeyleri
}

\author{
Middle School Students' Knowledge Level about Environmental Engineering
}

\author{
Ayşegül Ergün ${ }^{*}-$ Kadir Bilen ${ }^{* *}$
}

\begin{abstract}
One of the purposes of STEM education is to create awareness in the students about different engineering careers and guide them towards these careers. The aim of this study was to identify the knowledge levels of middle-school students on environmental engineering (EEKL) and to compare their knowledge level with the grade and gender variables. The sample of the study which was carried out in the 2017-2018 academic year consists of 335 students who were receiving education at public middle-school in the located in Demirci district of the city of Manisa. The descriptive survey model was used in the study with the purpose of identifying the existing EEKL of the students in the sample of the study without giving them any training or carrying out any applications. The "Environmental Engineering Knowledge Test", which consisted of three factors, and whose adaptation into Turkish and validity and reliability studies conducted by the authors was used as a data collection tool. In the research, the rules stated in the directives of higher education institutions scientific research and publication ethics were followed. In the analysis of the data, the independent groups t-test, one way variance analysis (ANOVA) were used. As a result of the study, it was determined that the students had middle level knowledge on environmental engineering and that there was a significant difference between the knowledge level of female and male students in the favor of the female students. It was found that as the grade level increased, EEKL increased and that there was a significant difference between the knowledge level of fifth grade students and the other grades. It was found that the effect of gender on EEKL was small and the effect of grade level on EEKL was medium. In the light of the obtained findings, it is suggested to give place to science, engineering and entrepreneurship applications about environmental engineering at early ages at school and environments outside schools.
\end{abstract}

*Dr. Öğr. Üyesi, Manisa Celal Bayar Üniversitesi, Eğitim Fakültesi, Matematik ve Fen Bilimleri Eğitimi Bölümü Assistant Prof. Dr., Manisa Celal Bayar University, Department of Mathematics and Science Education

Faculty of Education

ORCID 0000-0002-1481-4019

ergunaysegul@gmail.com

** Doç. Dr., Alanya Alaaddin Keykubat Üniversitesi, Eğitim Fakültesi, Matematik ve Fen Bilimleri Eğitimi Bölümü

Associate Prof. Dr., Alaaddin Keykubat University, Department of Mathematics and Science Education

Faculty of Education

ORCID 0000-0003-2054-2117

kadir.bilen@alanya.edu.tr

Araştırmaya ait etik kurul izni, Manisa Celal Bayar Üniversitesi Fen ve Mühendislik Bilimleri Bilimsel Araştırma ve Yayın Etiği Kurulunun 28.03.2018 tarihli ve E. 27968 sayı numaralı belgesi ile alınmıştır.

Cite as/ Atıf: Ergün, A. \& Bilen, K. (2020). Ortaokul öğrencilerinin çevre mühendisliği bilgi düzeyleri, Turkish Studies

- Education, 15(2), 783-804. https://dx.doi.org/10.29228/TurkishStudies.41618

Received/Geliş: 04 February/Şubat 2020

Checked by plagiarism software

Accepted/Kabul: 24 April/Nisan 2020

Published/Yayın: 30 April/Nisan 2020

Copyright (C) INTAC LTD, Turkey

CC BY-NC 4.0 
Structured Abstract: Introduction and Purpose of the Research: STEM education is an approach which deals with the disciplines of science, technology, engineering and mathematics in an integrated manner through in-class and extracurricular activities in all educational stages from kindergarten to university. The purpose of STEM education are to 1) educate STEM literate individuals who are able to solve the difficulties they face in daily life with the help of science, mathematics, engineering and technology; 2) create all research and development activities starting from the whole country in general and extending to classes based on innovations and innovative thinking and 3) train work power which has skills to be able to produce solutions to problems which are likely to be seen in the 21st century and cannot be solved through a single discipline. In Turkey, it can be stated that the purposes of the middle-school science lesson education program which has gone under certain changes in 2017 and 2018 and the purposes of STEM education which are grouped under 3 categories are similar. Middle-school years are extremely important in terms of career preference since these are years in which the perception, attitude and behaviors about different careers start taking shape and knowledge on careers is acquired. One of the purposes of STEM education is to create awareness in the students about different engineering careers and guide them towards these careers. In this respect, it is considered important that middle-school students' knowledge on the career of engineering is identified, because students' knowledge on engineering may affect their understanding and belief about engineering and their tendency to choose and continue this occupation as a career. The purpose of this study is to identify the knowledge levels of middle-school students on environmental engineering (EEKL) and to compare their knowledge level with the grade and gender variables. In the study, the answers to the following questions were sought with this purpose:

What is the level of middle-school students' EEKL?

Does the EEKL of middle-school students display a difference in terms of their gender?

Does the EEKL of middle-school students display a difference in terms of their grade levels?

Method: The descriptive survey model was used in the study with the purpose of identifying the existing EEKL of the students in the sample of the study without giving them any training or carrying out any applications. Researches which are descriptive survey models widely used in social sciences aim at revealing the attitudes, views or behaviors of individuals about the subject matter. This study was carried out in the spring semester of the 20172018 academic year. In the identification of the study sample, the convenience sampling method which is one of the purposeful sampling methods. In this sampling method, since the researcher chose a case which is close and easily accessible, it speeded up the research and made it more practical. The sample of the study consists of 335 students from 5th, 6th, 7th and 8th grades who were receiving education at a middle-school in the located in Demirci district of the city of Manisa. With the purpose of identifying the students' EEKL, as a result of the adaptation of the test to Turkish, it was determined that it consisted of a total of 20 items, 10 of which were about environmental engineering, 5 of which were about environmental pollution and 5 of which were about water cycle.

Results: According to the analysis results, the scores the female and male students received in general from the test are of middle level. It was seen that the knowledge level of the female students is higher compared to the male students and this difference is statistically significant $\left[\mathrm{t}_{(333)}=2.83, \mathrm{p}<.05\right]$. Similarly, it was determined that the knowledge level of the test in the environmental engineering dimension $\left[\mathrm{t}_{(333)}=2.16, \mathrm{p}<.05\right]$ and environmental pollution dimension $\left[\mathrm{t}_{(333)}=3.93, \mathrm{p}<.05\right]$ displayed a statistically significant difference in the favor of the female students. As for the knowledge level in the water cycle dimension, a statistically significant difference was not found in terms of gender $\left[\mathrm{t}_{(333)}=0.67, \mathrm{p}>.05\right]$. When the students' average scores are considered in terms of grade level, it was seen that the grades' knowledge levels are of medium level and as the grade level increases, the average score increases as well. There is a statistically significant difference between the knowledge levels of the grades in the test in general $\left[\mathrm{F}_{(3-331)}=9.245 ; \mathrm{p}<.05\right]$, environmental engineering $\left[\mathrm{F}_{(3-331)}=8.456 ; \mathrm{p}<.05\right]$ and environmental pollution $\left[\mathrm{F}_{(3-331)}=4.282 ; \mathrm{p}<.05\right]$ dimensions. It was determined that the difference in question was between the 5th grade students and 6th, 7th and 8th grade students in terms of the test in general and the environmental engineering dimension and between the 5th grade students and 6th and 7th grade students in the environmental pollution dimension. In addition, it was determined that the knowledge level of the 5th grade students was lower compared to the other grades. In the water cycle dimension, it was determined that there was no statistically significant difference between the grades' knowledge levels $\left[\mathrm{F}_{(3-331)}=3.090 ; \mathrm{p}>.05\right]$.

Discussion and Conclusion: As a result of the study, it was determined that the knowledge level of the middle-schools was of middle level. When it is considered that the students did not participate in any activity related to environmental engineering and that they were not given any information about environmental 
engineering prior to taking the test used in the study, it can be expressed that it is a pleasing result although an expected one. Similar to this finding, it was determined that in a study in which the 4th and 8th grade students' level of knowledge about engineering were compared according to different variables that the students' engineering knowledge was of middle level. In the study, it was determined that there was a significant difference in the favor of the female students when the students' knowledge level about environmental engineering was compared. Similar to this result, it was determined in another study that the knowledge level of 6th, 7th and 8th grade students on engineering displayed differences in the favor of the female students. However, it was concluded in the same study that the knowledge levels of the 4th and 5th grade students on engineering did not display any differences in terms of their gender (Aydın, Saka and Guzey, 2018). In the light of the findings obtained in this study, these are the suggestions made for the teachers: Students' attitude towards and interest in engineering careers are extremely important for them to obtain information about these careers. Therefore, it can be stated that it is important for teachers who work in STEM branches to carry out science, engineering and entrepreneurship applications in their classes and outside their classes. The science, engineering and entrepreneurship application dealt with in the EEKL used in this study was a water filter design. Teachers can apply this test as a pre-test and then ask the students to design water filters. Afterwards they can apply it as a post-test. In order to be able to determine the change in the students' knowledge on environmental engineering, drawings and the interview method can be used besides the test.

Keywords: Science Engineering And Entrepreneurship Applications, Environmental Engineering, Middle-School Student.

Öz: STEM eğitiminin amaçlardan birisi de, öğrencilerde farklı mühendislik kariyerlerine ilişkin bilinç oluşturmak ve öğrencileri bu kariyerlere yönlendirmektir. Dolayısıyla öğrencilerin mühendislik mesleğine ilişkin bilgilerinin araştırılması önemlidir. Bu araştırmanın amacı, ortaokul öğrencilerinin çevre mühendisliği bilgi düzeylerini (ÇMBD) belirlemek ve öğrencilerin bilgi düzeylerini sınıf ve cinsiyet değişkenlerine göre karşılaştırmaktır. 20172018 eğitim öğretim yılında gerçekleştirilen araştırmanın örneklemini, Manisa ilinin Demirci ilçesindeki bir devlet ortaokulunda öğrenim gören 335 öğrenci oluşturmaktadır. Araştırmada örneklemde yer alan öğrencilere herhangi bir öğretim veya uygulama yapılmadan, var olan ÇMBD’leri betimsel tarama modeli kullanılarak belirlenmiştir. Veri toplama aracı olarak araştırmacılar tarafından Türkçeye uyarlanarak geçerlik ve güvenirlik çalışması yapılan, üç faktörden oluşan "Çevre Mühendisliği Bilgi Testi” kullanılmıştır. Araştırmada yükseköğretim kurumları bilimsel araştırma ve yayın etiği yönergesinde belirtilen kurallara uyulmuştur. Verilerin analizinde bağımsız gruplar t testi, tek yönlü varyans analizi (ANOVA) kullanılmıştır. Araştırma sonucunda öğrencilerin çevre mühendisliğine ilişkin bilgilerinin orta düzeyde olduğu ve kız öğrencilerin bilgi düzeyleri ile erkek öğrencilerin bilgi düzeyleri arasında, kız öğrenciler lehine anlamlı farklılık olduğu belirlenmiştir. Sınıf düzeyi arttıkça ÇMBD’nin arttığı, beşinci sınıf öğrencilerinin bilgi düzeyi ile diğer sınıfların bilgi düzeyleri arasında anlamlı bir farklılık olduğu tespit edilmiştir. Cinsiyetin, ÇMBD üzerindeki etkisinin küçük büyüklükte olduğu, sınıf düzeyinin ÇMBD üzerindeki etkisinin ise orta büyüklükte olduğu bulunmuştur. Elde edilen sonuçlar 1şığında, çevre mühendisliğine yönelik fen, mühendislik ve girişimcilik uygulamalarına, okul ve okul dışı ortamlarda yer verilmesi önerilmiştir.

Anahtar Kelimeler: Fen Mühendislik Ve Girişimcilik Uygulamaları, Çevre Mühendisliği, Ortaokul Öğrencileri.

\section{Giriş}

Ülkemizde 2018 yılında yayınlanan fen bilimleri dersi öğretim programında, dördüncü sınıftan itibaren fen, mühendislik ve girişimcilik uygulamalarına yer verilmiştir. Bu uygulamalar sayesinde 21 . yüzyılın gerektirdiği iletişim, yaratıcılık, analitik düşünme, girişimcilik gibi yaşam becerilerine ve yenilikçi düşünme becerisine sahip nesiller yetiştirmek hedeflenmiştir (Milli Eğitim Bakanlığı [MEB], 2018). Fen, mühendislik ve girişimcilik uygulamalarının öğretim programına girmesiyle birlikte, ülkemizde STEM eğitimine yönelik ilginin arttığı ifade edilebilir. STEM eğitimi, okul içi ve okul dişı ortamlarda yürütülen etkinlikler vasıtasıyla bilim, teknoloji, mühendislik ve matematik disiplinlerinin bütüncül olarak ele alındığı bir yaklaşımdır (Daugherty, 2013). 
STEM eğitiminin birinci amacı, günlük yaşamda karşılaştıkları güçlükleri bilim, matematik, mühendislik ve teknoloji yardımıyla çözebilen, STEM okuryazarı bireyler yetiştirmek; ikinci amacı, ülke genelinden başlayarak sınıfların içine kadar uzanan araştırma ve geliştirme faaliyetlerini, yenilik ve yenilikçi düşünme üzerine kurmak; üçüncü amac1, 21. yüzyılda karşılaşılması muhtemel, tek bir disiplinin çözemediği problemlere çözüm üretebilecek becerilere sahip işgücünü yetiştirmek olarak sıralanmaktadır (Bybee, 2014). Fen bilimleri dersi öğretim programının amaçları ile üç başlık altında sıralanan STEM eğitiminin amaçlarının benzer oldukları söylenebilir.

Günümüzde toplumların mühendislik ve teknolojiye olan bağımlılıkları son derece artmıştır. Bu nedenle toplumu oluşturan her bireyin, mühendislerin ne yaptıklarını, mühendislerin geliştirdikleri teknolojilerin nasıl kullanıldığını ve hayatımızı nasıl etkilediklerini anlaması önemlidir (Pearson, 2004). Öğrencilerin, mühendislerin hangi alanlarda ne gibi işler yaptıklarını, mühendisliğin tasarım boyutunu, mühendislik ile bilim, teknoloji ve matematik arasındaki ilişkiyi diğer bir deyişle mühendisliğin doğasını doğru olarak anlamaları, STEM eğitiminin hedefine ulaşması açısından önemlidir.

Günlük hayatımız mühendisler tarafından tasarlanan birçok ürünle çevrili olmasına rağmen, çocukların ve çoğu yetişkinin teknoloji ve mühendislik hakkında çok az şey bildikleri; mühendislerin ne yaptığı ile ilgili yeterli bilgiye sahip olmadıkları belirtilmektedir (Frehill, 1997; Lachapelle ve Cunningham, 2007). Büyük bir çoğunlukla "teknoloji” teriminin sadece elektronik aletler ve bilgisayarlarla ilgili olduğunu düşündükleri ve mühendislik ile bilimin temelde aynı olduğuna inandıkları ifade edilmektedir (Lachapelle ve Cunningham, 2007). İçinde yaşadığımız insan yapımı ürünlerle çevrili dünyayı anlamak için küçük çocuklar da dâhil olmak üzere her bireyin, mühendislik ve teknoloji okuryazarlığını arttırmak önemlidir (Cunningham, 2009). Mühendislik ve teknoloji, STEM eğitiminde yer alan iki disiplinden biri olduğuna göre, STEM eğitimi ile yetiştirilmesi amaçlanan STEM okuryazarı bireylerin, mühendislik ve teknoloji okuryazarı olmalarının da amaçlandığı söylenebilir. Dolayısıyla öğrencilerin mühendislikle ilgili var olan bilgilerinin araştırılmasının önemli olduğu düşünülmektedir. Özellikle farklı mühendislik alanlarına yönelik var olan bilgi düzeylerinin belirlenmesi, STEM eğitiminde ne tür fen, mühendislik ve girişimcilik uygulamalarına yer verilmesi gerektiği noktasında araştırmacılara, program geliştiricilere ve öğretmenlere yol gösterici olabilir.

Literatürde ilkokul ve ortaokul öğrencilerinin mühendislikle ilgili algılarını ve bilgilerini belirlemeye yönelik çok sayıda araştırma bulunmaktadır (Aydın, Saka ve Guzey, 2018; Bilen, Irkıçatal ve Ergin, 2014; Carr, Diefes-Dux ve Horstman, 2012; Cunningham, Lachapelle ve Lingren-Streicher, 2005; Çakmak, Bilen ve Taner, 2019; Ergun ve Balcin, 2019; Fralick, Kearn, Thompson ve Lyons, 2009; Gülhan ve Şahin, 2018; Hirsch, Berliner-Heyman, Kimmel ve Carpinelli, 2011; Karatas, Micklos ve Bodner, 2011; Koyunlu Ünlü ve Dökme, 2017; Lachapelle ve Cunningham, 2007; Lachapelle, Phadnis, Hertel ve Cunningham, 2012). Örneğin Lachapelle vd. (2012), öğrencilerin mühendislerin bir şeyleri tasarlamaktan daha çok, genellikle araba ya da elektrikli aletler gibi şeyleri onardıkları bilgisine sahip olduklarını tespit etmiş̧ir. İlkokul öğrencilerinin mühendislerin ne yaptıklarına ilişkin bilgilerinin belirlendiği araştırmalarda, öğrenciler, çoğunlukla araba tamir etme, kablo döşeme, araç kullanma ve bina inşa etme cevaplarını vermiştir (Carr, Diefes-Dux ve Horstman, 2012; Cunningham, Lachapelle ve Lingren-Streicher, 2005).

Ortaokul öğrencileri ile gerçekleştirilen araştırmalarda en sık karşılaşılan yanılgıların, mühendislerin araba tamir eden, tren kullanan bireyler veya sıklıkla bilgisayar kullanarak yalnız çalışan kişiler (Bilen, Irkıçatal ve Ergin, 2014; Ergün, 2018; Ergun ve Balcin, 2019; Hirsch vd., 2011) veya zihinsel yönlerinden ziyade, ellerini kullanarak ağır işler yapan ve açık havada çalışan işçiler olarak algılanmas1 olduğu belirtilmiştir (Ergün, 2018; Ergun ve Balcin, 2019; Fralick vd., 2009). Yapılan araştırmalarda, öğrencilerin çoğunun mühendislik sürecini araç yapma, monte etme veya bina yapma olarak düşündükleri (Ergun ve Balcin, 2019; Gülhan ve Şahin, 2018; Karatas, Micklos ve Bodner, 2011; Koyunlu Ünlü ve Dökme, 2017); mühendislerin yaptıkları işlere yönelik algılarının yetersiz olduğu, çizimlerinde çoğunlukla ellerini kullanarak yapım, onarım işleri yapan ya da makine ve alet kullanan 
bireyler betimledikleri, mühendisleri çoğunlukla yalnız çalışan kişiler olarak algıladıkları (Ergün, 2018; Ergun ve Balcin, 2019) belirlenmiştir. Ortaokul öğrencilerinin mühendis algılarının belirlendiği diğer araştırmalarda, öğrencilerin çoğunlukla bina yapan ve bilgisayarla uğraşan mühendisler çizdikleri (Bilen, Irkıçatal ve Ergin, 2014; Gülhan ve Şahin, 2018; Koyunlu Ünlü ve Dökme, 2017) sınıf düzeyi arttıkça ziraat, genetik, makine, çevre gibi mühendislik alanlarının çizildiği (Gülhan ve Şahin, 2018) ve mühendisliğin tasarım yönünü betimleyen çizimlerin de olduğu (Ergun ve Balcin, 2019; Gülhan ve Şahin, 2018; Koyunlu Ünlü ve Dökme; 2017) belirlenmiştir. Çakmak, Bilen ve Taner (2019) araştırmalarında öğrencilerin, mühendislerin icat ve tasarım yaptıkları, hayatı kolaylaştırdıkları, işlerinde matematik kullandıkları bilgilerine sahip olduklarını, ancak mühendislik alanının çeşitliliğine ilişkin yeterli bilgiye sahip olmadıklarını; genelde inşaat ve bilgisayar mühendisi çizdiklerini tespit etmiştir. Aydın, Saka ve Guzey (2018) yaptıkları araştırmada, 4., 5., 6., 7. ve 8. sınıf öğrencilerinin mühendislik bilgi düzeylerini belirlemiştir. Araştırma sonucunda, öğrencilerin mühendislik bilgilerinin orta düzeyde olduğu; 4. ve 5. sınıf öğrencilerinin mühendislik bilgi düzeylerinin cinsiyetlerine göre farklılık göstermediği ancak 6., 7. ve 8. sınıf öğrencilerinin mühendislik bilgi düzeylerinin kızlar lehine farklılık gösterdiği belirlenmiştir. Ayrıca 5. sınıf öğrencilerinin mühendislik bilgi düzeylerinin, 4. sınıf öğrencilerine göre daha yüksek olduğu; 6., 7. ve 8. sınıf öğrencilerinin mühendislik bilgi düzeyleri arasında ise anlamlı bir farklılık bulunmadığ 1 tespit edilmiştir (Aydın, Saka ve Guzey, 2018). Yapılan çalışmalara bakıldığında, öğrencilerin genel olarak mühendislik mesleğine ilişkin bilgileri belirlenmekle birlikte, Balçın ve Ergün (2019) tarafından yapılan araştırmada ortaokul altıncı sınıf öğrencilerinin, havacılık ve uzay mühendislerinin yaptıkları işleri astronom ve astronotların yaptıkları işlerle karıştırdıkları sonucuna ulaşılmıştır.

Ortaokul yılları, farklı mesleklere yönelik algı, tutum ve davranışların şekillenmeye başladığı, meslekler hakkında bilgilerin kazanıldığı bir dönem olduğundan, kariyer seçimi açısından oldukça önemlidir (Gottfredson, 2002). STEM eğitiminin amaçlardan birisi de öğrencilerde farklı mühendislik kariyerlerine ilişkin bilinç oluşturmak ve öğrencileri STEM alanlarındaki kariyerlere yönlendirmektir. $\mathrm{Bu}$ bağlamda ortaokul öğrencilerinin mühendislik mesleğine ilişkin bilgilerinin ortaya çıkarılmasının önemli olduğu düşünülmektedir. Çünkü öğrencilerin mühendisliğe ilişkin bilgileri, bu mesleğe dair inançlarını ve mesleği kariyer olarak seçme eğilimlerini etkileyebilir (Knight ve Cunningham, 2004).

Çevre mühendisliği, doğal kaynakları korumak ve verimli bir şekilde kullanılmasını sağlamak; doğayı insanın etkisinden, insan sağlığını da kirlenen çevrenin etkilerinden korumak adına araştırma ve teknoloji geliştirme çalışmaları yapan çok disiplinli bir mühendislik dalıdır (Topal ve Arslan, 2010). Çevre mühendisliğinin amaçları göz önüne alındığında, çevre mühendisliği hakkında bilgi sahibi olan öğrencilerin, bu mesleğe ilişkin kariyer bilincinin yanı sıra, sürdürülebilir kalkınma bilincine de sahip olacakları düşünülmektedir. Günümüzde ortaokul seviyesinde öğrenim gören öğrenciler, gelecekte meydana gelebilecek çevre sorunlarının çözümünde aktif olarak görev alacak olan bireyler olduğundan, çevre mühendisliği hakkındaki bilgi seviyelerinin belirlenmesi ve onların bu alana ilgi duymaları son derece önem taşımaktadır.

$\mathrm{Bu}$ araştırmanın amacı, ortaokul öğrencilerinin çevre mühendisliği bilgi düzeylerini (ÇMBD) belirlemek ve öğrencilerin bilgi düzeylerini sınıf ve cinsiyet değişkenlerine göre karşlaştırmaktır. Bu amaçla araştırmada aşağıdaki sorulara cevap aranmıştır.

Öğrencilerin çevre mühendisliği bilgi düzeyleri nasıldır?

Öğrencilerin çevre mühendisliği bilgi düzeyleri cinsiyetlerine göre değişmekte midir?

Öğrencilerinin çevre mühendisliği bilgi düzeyleri sınıf düzeylerine göre değişmekte midir? 


\section{Yöntem}

\section{Araştırma Deseni}

Araştırmada örneklemde yer alan öğrencilere herhangi bir öğretim veya uygulama yapılmadan, var olan ÇMBD'leri betimsel tarama modeli kullanılarak belirlenmiştir. Betimsel tarama modelindeki araştırmalar, bireylerin çalışılan araştırma konusuna ilişkin görüşlerini, tutumlarını veya davranışlarını belirlemeyi amaçlar (Creswell, 2008).

\section{Örneklem}

Araştırma, 2017-2018 eğitim öğretim yılının ikinci döneminde gerçekleştirilmiştir. Araştırmanın örneklemi, kolay ulaşılabilir durum örneklemesi ile belirlenmiştir. Bu yöntemde, kolay ulaşılabilecek bir durum seçilir ve araştırmaya hız kazandırılır (Yıldırım ve Şimşek, 2016). Araştırmanın örneklemini, Manisa ilinin Demirci ilçesindeki bir devlet ortaokulunda öğrenim gören 335 öğrenci meydana getirmektedir. Örneklemin demografik bilgileri Tablo 1'de verilmiştir.

Tablo 1: Örneklemin Demografik Bilgileri

\begin{tabular}{ccccc}
\hline Kategori & Sinıflama & Öğrenci Sayısı & Yüzde (\%) \\
\hline \multirow{3}{*}{ Sınıf düzeyi } & 5 & 124 & 37.01 \\
& \multicolumn{1}{c}{ Cinsiyet } & 7 & 83 & 24.77 \\
\cline { 2 - 4 } & \multicolumn{1}{c}{ Kiz } & 77 & 22.98 \\
\cline { 2 - 4 } & Erkek & 175 & 15.22 \\
\cline { 2 - 4 } & & 160 & 52.24 \\
\hline & Toplam & & 335 & 47.76 \\
\hline
\end{tabular}

\section{Araştırma Etiği}

$\mathrm{Bu}$ araştırmada yükseköğretim kurumları bilimsel araştırma ve yayın etiği yönergesinde belirtilen kurallara uyulmuştur. Yönergede belirtilen bilimsel araştırma ve yayın etiğine aykırı eylemlerden hiçbiri araştırmada gerçekleştirilmemiştir. Araştırmaya ait etik kurul izni, Manisa Celal Bayar Üniversitesi Fen ve Mühendislik Bilimleri Bilimsel Araştırma ve Yayın Etiği Kurulunun 28.03.2018 tarihli ve E. 27968 sayı numaralı belgesi ile alınmıştır. Etik kurul belgesi Ek 3'te sunulmuştur.

\section{Veri Toplama Aracı}

Araştırmada Engineering is Elementary (Mühendislik Temeldir) tarafından geliştirilen "Designing Water Filters Instrument" isimli ölçme aracı kullanılmıştır (Engineering is Elementary [EiE], 2018). Öğrenci seviyesine uygun olarak 4 seçenekli 25 soru ve 3 boyuttan oluşan orijinal ölçme aracının Cronbach alpha değeri 697 olarak hesaplanmışır. Ölçme aracının boyutları ve bu boyutlardaki sorulara ait bilgiler Tablo 2'de sunulmuştur.

Tablo 2: Ölçme Aracının Boyutları ve İlgili Sorular

\begin{tabular}{lll}
\hline Faktör & Madde sayısı & Maddeler \\
\hline Çevre Mühendisliği & 13 & $\begin{array}{l}1,2,4,5,6,12,14,15,20,21,22, \\
23,24\end{array}$ \\
\hline Çevre Kirliliği & 6 & $7,13,16,17,18,19$ \\
\hline Su döngüsü & 6 & $3,8,9,10,11,25$ \\
\hline
\end{tabular}

Araştırmacıların kullanımına açık bir şekilde, Engineering is Elementary tarafından internet ortamında paylaşılan ölçme aracını, araştırma soruları doğrultusunda kullanabilmek için öncelikle İngilizceden Türkçeye çevirisi yapılarak dil geçerliği sağlanmıştır. Uyarlama çalışmalarında, ifadelerin 
uyarlama yapılacak dile uyum sağlaması çok önemlidir. İngilizce ölçme aracının Türkçeye çevirisi iki etapta gerçekleştirilmiştir. İlk etapta, Türkçe ve İngilizceye hâkim iki çeviri uzmanı birbirinden bağımsız bir şekilde Türkçe çeviri yapmıştır. İkinci etapta, bir çeviri uzmanı ve iki araştırmacı çevirileri karşılaştırmış ve maddeleri en iyi ifade ettiği konusunda fikir birliğine varılan çeviriler kabul edilmiştir. Fen bilgisi eğitimi anabilim dalında görevli iki akademisyen, ölçme aracının Türkçe formunun son halini inceleyerek uzlaşmaya varmışlardır. Soruların anlaşılabilirliğinin belirlenmesi amacı ile ölçme aracı, toplam 40 öğrenciye uygulanmıştır. Elde edilen sonuçlara göre soruların anlaşılmasında bir sorun olmadığı belirlenmiş; ölçme aracı geçerlik ve güvenirlik çalışması için hazır hale getirilmiştir.

Ölçme aracının geçerliği, ölçmeyi amaçladığı niteliği, diğer bir nitelikle karıştırmadan doğru bir şekilde ölçebilmesidir (Büyüköztürk, 2018). Ölçme aracının kapsam geçerliğini arttırma amacı ile belirtke tablosu hazırlanmaktadır (Büyüköztürk vd., 2012). Araştırmada kullanılacak ölçme aracının kapsam geçerliği için öğretim programındaki (MEB, 2018) kazanımlara göre hazırlanan belirtke tablosu Tablo 3'te sunulmuştur. Hazırlanan belirtke tablosu ve sorular fen bilgisi eğitiminde uzman iki akademisyen ve bir fen bilgisi öğretmeninin görüşüne sunulmuştur. Alınan görüşler doğrultusunda düzeltmeler yapılarak ölçme aracına son hali verilmiştir. Yapılan görüşmelerde test sorularının boyutları ve kapsamı göz önünde bulundurularak Çevre Mühendisliği Bilgi Testi (ÇMBT) olarak adlandırılmasına karar verilmiştir.

Tablo 3: ÇMBT'ne Ait Belirtke Tablosu

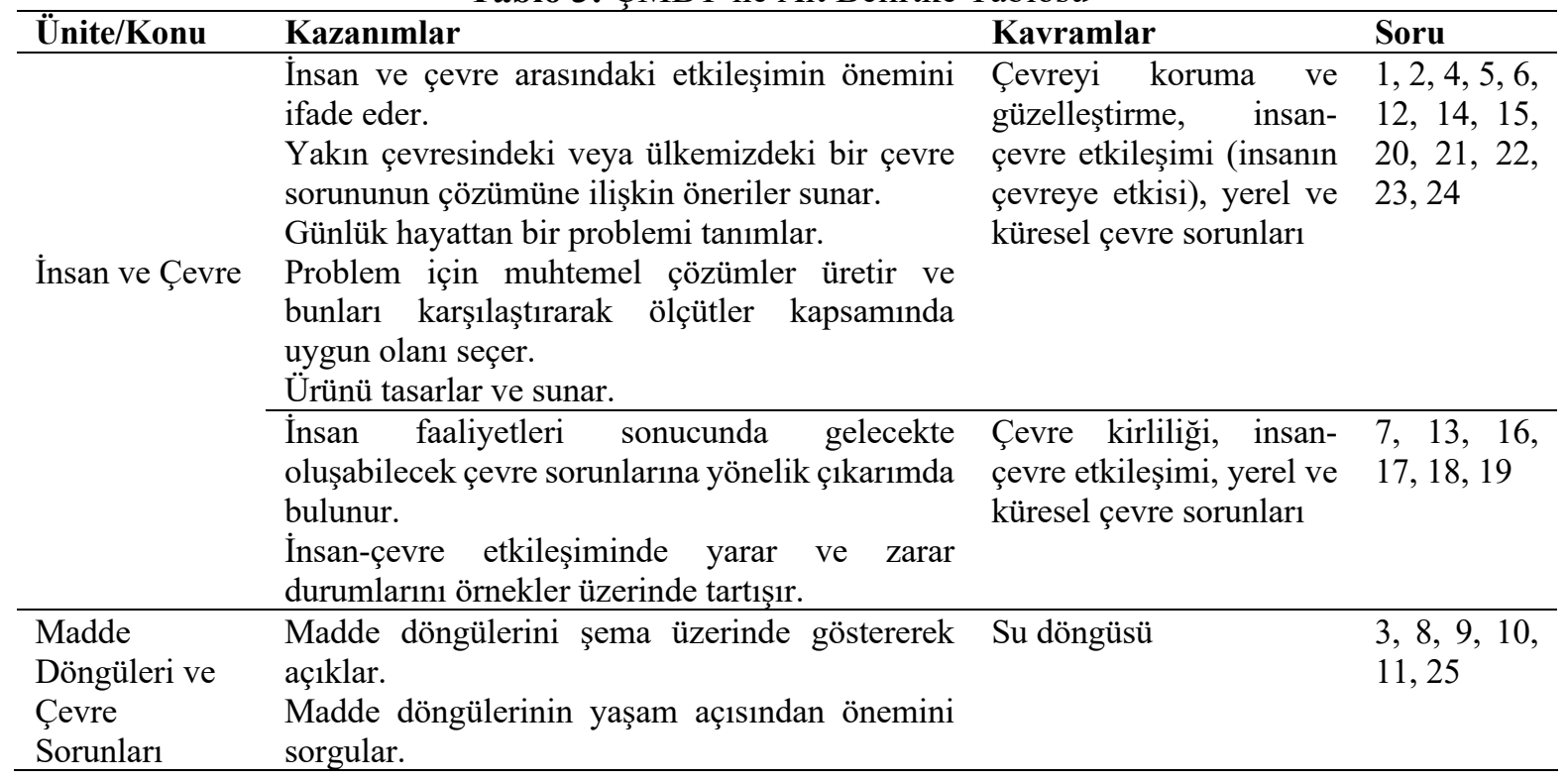

Bir ölçme aracının geçerliğini artırmanın diğer bir yolu da madde analizidir (Tan, 2014). Madde analizinde örneklemin, madde sayısının en az iki katı, tercihen 10 katı olması önerilmektedir (Büyüköztürk vd., 2012). Bu nedenle 25 maddeden oluşan ölçme aracının madde analizi için araştırma örneklemindeki 335 öğrenci içerisinden, her sınıf seviyesinden 50 öğrenci rastgele seçilmiş ve 200 öğrenci ile madde analizi gerçekleştirilmiştir.

\section{Madde Analizine İlişskin Bulgular}

ÇMBT'de bulunan çoktan seçmeli 25 sorunun her birinin bir doğru cevabı bulunmaktadır ve yanlış yanıtlar, doğru yanıtları etkilememektedir. Öğrencilerin sorulara verdikleri cevapların şıkları önce MS Excel programına girilmiş; ardından TAP'a (Test Analysis Program) aktarılmıştır. Programa cevap anahtarı da girilerek analiz yapılmıştır. Analiz sonucunda her bir maddeye \%27'lik alt grupta ve üst 
grupta doğru cevap veren öğrenci sayılarına göre ulaşılan, madde güçlük indeksi (p) ve madde ayırt edicilik indeksi (r) değerleri Tablo 4'te sunulmuştur.

Tablo 4: Alt ve Üst Gruplardaki Doğru Cevap Sayısına Göre Madde Güçlük (p) ve Ayırt Edicilik (r) İndeksleri

\begin{tabular}{|c|c|c|c|c|c|c|c|}
\hline Madde & Dü & Da & p & Güçlük & $\mathbf{r}$ & Ayırt edicilik & Sonuç \\
\hline 1 & 3 & 0 & 0.63 & Kolay & 0.40 & Çok iyi & Kalmalı \\
\hline 2 & 6 & 4 & 0.48 & Orta & 0.41 & Çok iyi & Kalmalı \\
\hline 3 & 38 & 18 & 0.43 & Orta & 0.19 & Çok zayıf & Çıkarılmalı \\
\hline 4 & 60 & 23 & 0.69 & Kolay & 0.45 & Çok iyi & Kalmalı \\
\hline 5 & 33 & 14 & 0.34 & Zor & 0.32 & İyi & Kalmalı \\
\hline 6 & 51 & 16 & 0.53 & Orta & 0.45 & Çok iyi & Kalmalı \\
\hline 7 & 60 & 18 & 0.62 & Kolay & 0.54 & Çok iyi & Kalmalı \\
\hline 8 & 68 & 29 & 0.81 & Çok kolay & 0.46 & Çok iyi & Kalmalı \\
\hline 9 & 64 & 22 & 0.73 & Kolay & 0.53 & Çok iyi & Kalmalı \\
\hline 10 & 41 & 16 & 0.36 & Zor & 0.30 & İyi & Kalmalı \\
\hline 11 & 55 & 33 & 0.71 & Kolay & 0.30 & İyi & Kalmalı \\
\hline 12 & 64 & 27 & 0.77 & Kolay & 0.44 & Çok iyi & Kalmalı \\
\hline 13 & 36 & 14 & 0.43 & Orta & 0.31 & İyi & Kalmalı \\
\hline 14 & 57 & 13 & 0.54 & Orta & 0.59 & Çok iyi & Kalmalı \\
\hline 15 & 33 & 10 & 0.33 & Zor & 0.30 & $\dot{\text { İyi }}$ & Kalmalı \\
\hline 16 & 63 & 17 & 0.61 & Kolay & 0.60 & Çok iyi & Kalmalı \\
\hline 17 & 16 & 4 & 0.14 & Çok zor & 0.16 & Zayıf & Çıkarılmalı \\
\hline 18 & 31 & 7 & 0.32 & Zor & 0.32 & İyi & Kalmalı \\
\hline 19 & 31 & 10 & 0.28 & Zor & 0.30 & İyi & Kalmalı \\
\hline 20 & 59 & 10 & 0.59 & Orta & 0.67 & Çok iyi & Kalmalı \\
\hline 21 & 40 & 16 & 0.41 & Orta & 0.31 & İyi & Kalmalı \\
\hline 22 & 23 & 15 & 0.28 & Zor & 0.06 & Çok zayıf & Çıkarılmalı \\
\hline 23 & 10 & 8 & 0.15 & Çok zor & 0.00 & Çok zayıf & Çıkarılmalı \\
\hline 24 & 29 & 15 & 0.34 & Zor & 0.15 & Çok zayıf & Çıkarılmalı \\
\hline 25 & 45 & 9 & 0.44 & Orta & 0.49 & Çok iyi & Kalmalı \\
\hline
\end{tabular}

Dü: Maddeyi üst grupta doğru cevaplayan öğrencilerin sayısı

Da: Maddeyi alt grupta doğru cevaplayan öğrencilerin sayıs1

Tablo 4'e göre, ölçekteki maddelerin güçlük indeksleri .14 ile .81 arasında, ayırt edicilik indeksleri .00 ile .67 arasındadır. Testin ortalama madde güçlük değeri $(p=.479)$, ortalama ayırt edicilik değeri $(\mathrm{r}=.352)$ ve K20 güvenirlik katsayısı ise .655 olarak hesaplanmıştır. Madde güçlük indeksi değerinin (p) 0'a yaklaşması, maddenin zorlaştığını, 1'e yaklaşması maddenin kolaylaştı̆̆ını ifade etmektedir. İdeal bir maddenin $p$ değerinin ve bir ölçme aracının ortalama p değerinin $0.40-0.60$ arasında olması beklenmektedir (Gömleksiz ve Erkan, 2010); p değeri 0.20-0.90 aralığındaki maddeler kabul edilebilirken p değeri bu aralığın dışında olan maddeler ölçme aracından çıkarılmalıdır (Boopathiraj ve Chellamani, 2013). Buna göre; iki maddenin (17 ve 23) testten çıkarılmasına karar verilmiştir. Bu iki madde dışındaki maddelerin orta güçlükte oldukları belirlenmiştir.

Ayırt edicilik, bir ölçme aracının ölçmeyi hedeflediği özelliği yüksek düzeyde bulunduran bireylerle, düşük düzeyde bulunduran bireyleri ayırt edebilme gücüdür. Madde ayırt edicilik indeksi değeri (r) 0'a yakın maddelerin ayırt ediciliği düşük, ayırt edicilik indeksi değeri 1'e yakın maddelerin ayırt ediciliği yüksektir. Madde ayırt edicilik indeksinin negatif değerler alması, alt gruptaki öğrencilerin maddeyi doğru yanıtlama oranının, üst gruptaki öğrencilere göre daha fazla olduğunu belirtmektedir. Böyle bir madde test güvenirliğini düşürdüğünden (Büyüköztürk vd., 2012; Kubiszyn ve Borich, 2003) testten çıkarılmalıdır (Tan, 2014). Bu değerler göz önüne alınarak 5 maddenin $(3,17,22,23$ ve 24) testten çıkarılmasına karar verilmiştir. Maddeler çıkarıldıktan sonra kalan 20 maddelik test, tekrar madde analizine tabi tutulmuştur. Analiz sonucunda testin ortalama madde güçlük değeri $(p=.532)$, 
ortalama ayırt edicilik değeri $(r=.436)$ ve K20 güvenirlik katsayısı ise .701 olarak hesaplanmıştır; bu değerler 20 soruluk testin geçerli ve güvenilir olduğunu göstermektedir. Dolayısıyla ÇMBT'nin bu araştırmanın alt problemlerine yanıt bulmak için kullanılabileceği ifade edilebilir. Türkçeye uyarlanarak geçerlik ve güvenirlik çalışması yapılan 20 soruluk testin boyutları ve bu boyutlarda yer alan sorulara ilişkin bilgiler Tablo 5'te sunulmuştur. Uyarlanan teste ait belirtke tablosu ise Ek 2'de verilmiştir.

Tablo 5: Uyarlanan Ölçme Aracının Boyutları ve İlgili Sorular

\begin{tabular}{lll}
\hline Faktör & Madde sayısı & Maddeler \\
\hline Cevre Mühendisliği & 10 & $1,2,3,4,5,11,13,14,18,19$ \\
\hline Çevre Kirliliği & 5 & $6,12,15,16,17$ \\
\hline Su döngüsü & 5 & $7,8,9,10,20$ \\
\hline
\end{tabular}

Fen Bilgisi Eğitiminde uzman iki akademisyenin de görüşleri alınarak, uyarlanan testin 3 faktörlü yapısının ve faktörlerde yer alan maddelerin, orijinal testteki faktör yapısı ve maddelerle örtüştüğüne karar verilmiştir. Araştırmada kullanılan 20 soruluk ÇMBT Ek 1'de verilmiştir. Öğrencilere test sorularını yanıtlamaları için bir ders saati süre verilmiş, sınıf ve cinsiyet dışında herhangi bir bilgi istenmemiştir.

\section{Verilerin Analizi}

Araştırmada, ÇMBT'nin madde analizinin yapılmasında MS Excel ile TAP (Test Analysis Program) programları birlikte kullanılmış; madde güçlük ve madde ayırt edicilik indeksleri ve KR-20 katsayısı hesaplanmıştır. Türkçeye uyarlanarak geçerlik ve güvenirlik analizleri sonucu 20 sorudan oluşturulan ÇMBT'den alınabilecek en yüksek puan 20, alınabilecek en düşük puan 0 olarak belirlenmiştir. Her bir doğru cevaba 1 puan verilmiş, boş veya yanlış cevaba ise puan verilmemiştir. ÇMBT'den alınan puanlar derecelendirilmiş ve 0-6 puan aralığı düşük, 7-13 puan aralığı orta, 14-20 puan aralığı iyi düzey olarak yorumlanmıştır. Testin örneklem grubundaki öğrencilere uygulanmasının ardından, alınan puanların değişkenlere göre normal dağılım durumu incelenmiştir. Yapılan normal dağılım analizine ilişkin sonuçlar Tablo 6' da verilmiştir.

Tablo 6: Değişkenlere Göre ÇMBT Normal Dağılım Analiz Sonuçları

\begin{tabular}{lllllll}
\hline Değişkenler & Çarpıklık & $\begin{array}{l}\text { Çarpıklık } \\
\text { Standart Hata }\end{array}$ & Basıklık & $\begin{array}{l}\text { Basıklık } \\
\text { Standart Hata }\end{array}$ & Ortalama & $\begin{array}{l}\text { Standart } \\
\text { Sapma }\end{array}$ \\
\hline Cinsiyet & .090 & .133 & 1.424 & .266 & 1.48 & .500 \\
\hline Sinıf düzeyi & .384 & .133 & 1.195 & .266 & 6.16 & 1.08 \\
\hline
\end{tabular}

+1.5 ile -1.5 arasındaki çarpıklık ve basıklık değerleri, verilerin normal dağıldığını ifade etmektedir (Tabachnick ve Fidell, 2007). Tablo 6'daki değerler incelendiğinde, değişkenlere göre ÇMBT'den elde edilen verilerin normal dağıldığ 1 belirlenmiş ve verilerin analizinde bağımsız gruplar t testi ve ilişkisiz örneklemler için tek yönlü varyans analizi (ANOVA) kullanılmıştır. ANOVA analizi neticesinde anlamlı bulunan sonuçların hangi gruplar lehine olduğunu tespit etmek için, Levene testi sonucu varyansların eşit olduğu $(\mathrm{p}>.05)$ belirlendiğinden Tukey testi kullanılmıştır.

Cinsiyetin, çevre mühendisliği bilgi düzeyi üzerindeki etkisini belirlemek için etki boyutunu gösteren Cohen's d değeri hesaplanmıştır; d değeri, işaretinden bağımsız olarak değerlendirilir ve her değeri alabilir; d'nin aldığı, $0.2,0.5$ ve 0.8 değerleri sırayla küçük, orta ve büyük etki şeklinde değerlendirilir (Green ve Salkind, 2005; s.169). Sınıf düzeyinin, çevre mühendisliği bilgi düzeyi üzerindeki etkisini belirlemek için etki boyutunu gösteren eta kare $\left(\eta^{2}\right)$ değeri hesaplanmıştır; $\eta^{2}$ 'nin aldığı $0.01,0.06$ ve 0.14 değerleri sırayla küçük, orta ve geniş etki şeklinde yorumlanır (Green ve Salkind, 2005, s.157). 


\section{Bulgular}

\section{Öğrencilerin Çevre Mühendisliği Bilgi Düzeylerine İlişsin Bulgular}

Öğrencilerin ÇMBD'lerini belirleyebilmek için test ve alt boyutlarından aldıkları puanların betimsel analizi yapılarak bulgular Tablo 7'de sunulmuştur.

Tablo 7: Test ve Alt Boyutlarından Alınan Puanların Betimsel Analiz Sonuçları

\begin{tabular}{llllll}
\hline Test ve Alt Boyutları & N & Minimum & Maksimum & Ortalama & Standart Sapma \\
\hline Test (20 madde) & 335 & 1 & 20 & 11.27 & 3.70 \\
\hline Çevre Mühendisliği (10 madde) & 335 & 0 & 10 & 5.70 & 2.15 \\
\hline Çevre Kirliliği (5 madde) & 335 & 0 & 5 & 2.41 & 1.47 \\
\hline Su döngüsü (5 madde) & 335 & 0 & 5 & 3.16 & 1.29 \\
\hline
\end{tabular}

Tablo 7'deki analiz sonuçlarına göre, öğrencilerin ÇMBT'den ve alt boyutlarından aldıkları puanların orta düzeyde olduğu belirlenmiştir.

\section{Öğrencilerin Cinsiyetlerine Göre Çevre Mühendisliği Bilgi Düzeylerine İlişkin Bulgular}

Öğrencilerin ÇMBT'den aldıkları puanların cinsiyetlerine göre değişip değişmediği bağımsız örneklemler t testi ile incelenmiştir; analiz sonuçları Tablo 8'de sunulmuştur.

Tablo 8: ÇMBT ve Alt Boyutlarından Alınan Puanların Cinsiyete Göre Bağımsız Örneklemler t Testi

\begin{tabular}{|c|c|c|c|c|c|c|c|c|}
\hline \multicolumn{9}{|c|}{ Analiz Sonuçları } \\
\hline Test ve Alt Boyutları & Cinsiyet & $\mathbf{N}$ & $\overline{\boldsymbol{X}}$ & $\mathbf{S}$ & sd & $\mathbf{t}$ & $p$ & $\begin{array}{l}\text { Cohen's } \\
\text { d }\end{array}$ \\
\hline \multirow{2}{*}{ Test (20 madde) } & $\mathrm{K} 1 \mathrm{z}$ & 175 & 11.82 & 3.65 & \multirow{2}{*}{333} & \multirow{2}{*}{2.83} & \multirow[t]{2}{*}{$.005^{*}$} & \multirow{2}{*}{.31} \\
\hline & Erkek & 160 & 10.68 & 3.68 & & & & \\
\hline \multirow{2}{*}{$\begin{array}{l}\text { Çevre Mühendisliği (10 } \\
\text { madde) }\end{array}$} & Kiz & 175 & 5.94 & 2.14 & \multirow[t]{2}{*}{333} & \multirow[t]{2}{*}{2.16} & \multirow[t]{2}{*}{$.031^{*}$} & \multirow[t]{2}{*}{.23} \\
\hline & Erkek & 160 & 5.44 & 2.13 & & & & \\
\hline \multirow{2}{*}{$\begin{array}{lll}\text { Çevre } & \text { Kirliliği } & (5 \\
\text { madde) } & & \\
\end{array}$} & $\mathrm{K} 1 \mathrm{Z}$ & 175 & 2.71 & 1.49 & \multirow[t]{2}{*}{333} & \multirow[t]{2}{*}{3.93} & \multirow[t]{2}{*}{$.000^{*}$} & \multirow[t]{2}{*}{.43} \\
\hline & Erkek & 160 & 2.09 & 1.38 & & & & \\
\hline \multirow[t]{2}{*}{ Su döngüsü (5 madde) } & $\mathrm{K} 1 \mathrm{Z}$ & 175 & 3.17 & 1.28 & \multirow[t]{2}{*}{333} & \multirow[t]{2}{*}{.067} & \multirow[t]{2}{*}{.947} & \\
\hline & Erkek & 160 & 3.16 & 1.30 & & & & \\
\hline
\end{tabular}

Tablo 8'deki analiz sonuçlarına göre, öğrencilerin test genelinden aldıkları puanlar, orta düzeyde olup kız öğrencilerin bilgi düzeyi, erkek öğrencilerin bilgi düzeyine göre daha yüksektir ve bu fark anlamlı bulunmuştur [ $\left.\mathrm{t}_{(333)}=2.83, \mathrm{p}<.05\right]$. Ancak, Cohen's d etki büyüklüğü değerine (.31) göre, cinsiyetin çevre mühendisliği bilgi düzeyi üzerindeki etkisinin küçük büyüklükte olduğu belirlenmiştir.

Tablo 8'e göre, testin çevre mühendisliği boyutundaki $\left[\mathrm{t}_{(333)}=2.16, \mathrm{p}<.05\right]$ ve çevre kirliliği boyutundaki $\left[\mathrm{t}_{(333)}=3.93, \mathrm{p}<.05\right]$ bilgi düzeyinin de kız öğrenciler lehine istatistiksel olarak anlamlı bir şekilde farklılaştığı belirlenmiştir. Cohen's d etki büyüklüğü değerlerine bakıldığında ise cinsiyetin, testin çevre mühendisliği boyutundaki bilgi düzeyine etkisinin (.23) küçük büyüklükte; çevre kirliliği boyutundaki bilgi düzeyine etkisinin de (.43) küçük büyüklükte olduğu tespit edilmiştir. Su döngüsü boyutundaki bilgi düzeyinde ise cinsiyete göre, anlamlı bir farlılık bulunmamıştır [ $\left.\mathrm{t}_{(333)}=0.67, \mathrm{p}>.05\right]$.

\section{Bulgular}

Öğrencilerin Sınıf Düzeylerine Göre Çevre Mühendisliği Bilgi Düzeylerine İlişkin

Öğrencilerin ÇMBT’den aldıkları puanların sınıf düzeylerine göre değişip değişmediğini tespit etmek için test ve alt boyutlarından alınan puanların betimsel analizi yapılarak bulgular Tablo 9'da sunulmuştur. 
Tablo 9: ÇMBT ve Alt Boyutlarından Alınan Puanların Sınıf Düzeyine Göre Betimsel Analiz Sonuçları

\begin{tabular}{|c|c|c|c|c|c|c|}
\hline Test ve Alt Boyutları & Sinıf & $\mathbf{N}$ & $\overline{\boldsymbol{X}}$ & $\mathbf{S}$ & Minimum & Maximum \\
\hline \multirow{5}{*}{$\begin{array}{l}\text { Test } \\
\text { (20 madde) }\end{array}$} & 5 & 124 & 9.94 & 3.55 & 2.00 & 20.00 \\
\hline & 6 & 83 & 11.88 & 3.59 & 3.00 & 18.00 \\
\hline & 7 & 77 & 12.10 & 3.70 & 1.00 & 19.00 \\
\hline & 8 & 51 & 12.27 & 3.38 & 2.00 & 19.00 \\
\hline & Toplam & 335 & 11.27 & 3.70 & 1.00 & 20.00 \\
\hline \multirow{5}{*}{ Çevre Mühendisliği (10 madde) } & 5 & 124 & 4.99 & 2.12 & 0.00 & 10.00 \\
\hline & 6 & 83 & 5.92 & 2.04 & 1.00 & 10.00 \\
\hline & 7 & 77 & 6.09 & 2.21 & 0.00 & 10.00 \\
\hline & 8 & 51 & 6.49 & 1.80 & 1.00 & 9.00 \\
\hline & Toplam & 335 & 5.70 & 2.15 & 0.00 & 10.00 \\
\hline \multirow{5}{*}{ Çevre Kirliliği (5 madde) } & 5 & 124 & 2.06 & 1.46 & 0.00 & 5.00 \\
\hline & 6 & 83 & 2.63 & 1.49 & 0.00 & 5.00 \\
\hline & 7 & 77 & 2.74 & 1.41 & 0.00 & 5.00 \\
\hline & 8 & 51 & 2.41 & 1.43 & 0.00 & 5.00 \\
\hline & Toplam & 335 & 2.41 & 1.47 & 0.00 & 5.00 \\
\hline \multirow{5}{*}{ Su döngüsü (5 madde) } & 5 & 124 & 2.88 & 1.30 & 0.00 & 5.00 \\
\hline & 6 & 83 & 3.34 & 1.29 & 0.00 & 5.00 \\
\hline & 7 & 77 & 3.27 & 1.28 & 0.00 & 5.00 \\
\hline & 8 & 51 & 3.37 & 1.18 & 0.00 & 5.00 \\
\hline & Toplam & 335 & 3.16 & 1.29 & 0.00 & 5.00 \\
\hline
\end{tabular}

Tablo 9'da görüldüğü üzere, testin tamamından alınan ortalama puanlara göre, sınıfların bilgi düzeyleri orta seviyededir ve sınıf seviyesi arttıkça ortalama puan da artmaktadır. Sınıflar arasındaki farklılığın anlamlı olup olmadığını tespit etmek amacı ile yapılan tek yönlü varyans analizinin sonucu Tablo 10'da sunulmuştur.

Tablo 10: ÇMBT ve Alt Boyutlarından Alınan Puanların Sınıf Düzeyine Göre One-Way ANOVA Testi Analiz Sonuçları

\begin{tabular}{|c|c|c|c|c|c|c|c|c|}
\hline $\begin{array}{l}\text { Test ve Alt } \\
\text { Boyutları }\end{array}$ & $\begin{array}{l}\text { Varyansın } \\
\text { Kaynağı }\end{array}$ & $\begin{array}{l}\text { Kareler } \\
\text { Toplamı }\end{array}$ & d & $\begin{array}{l}\text { Kareler } \\
\text { Ortalaması }\end{array}$ & $\mathbf{F}$ & p & $\begin{array}{l}\text { Eta } \\
\text { kare } \\
\eta^{2}\end{array}$ & $\begin{array}{l}\text { Anlamlı } \\
\text { Fark }\end{array}$ \\
\hline \multirow{3}{*}{$\begin{array}{l}\text { Test } \\
\text { (20 madde) }\end{array}$} & Gruplar arası & 354.009 & 3 & 118.003 & \multirow[t]{3}{*}{9.245} & \multirow[t]{3}{*}{$.000^{*}$} & \multirow[t]{3}{*}{.07} & $5-6$ \\
\hline & Gruplar içi & 4224.726 & 331 & 12.764 & & & & $5-7$ \\
\hline & Toplam & 4578.734 & 334 & & & & & $5-8$ \\
\hline \multirow{3}{*}{$\begin{array}{l}\text { Çevre } \\
\text { Mühendisliği (10 } \\
\text { madde) }\end{array}$} & Gruplar arası & 109.639 & 3 & 36.546 & \multirow[t]{3}{*}{8.456} & \multirow[t]{3}{*}{$.000^{*}$} & \multirow[t]{3}{*}{.07} & $5-6$ \\
\hline & Gruplar içi & 1430.510 & 331 & 4.322 & & & & $5-7$ \\
\hline & Toplam & 1540.149 & 334 & & & & & $5-8$ \\
\hline \multirow{3}{*}{$\begin{array}{l}\text { Çevre Kirliliği } \\
\text { ( } 5 \text { madde) }\end{array}$} & Gruplar arası & 27.089 & 3 & 9.030 & \multirow[t]{3}{*}{4.282} & \multirow[t]{3}{*}{$.006^{*}$} & \multirow[t]{3}{*}{.04} & $5-6$ \\
\hline & Gruplar içi & 698.064 & 331 & 2.109 & & & & $5-7$ \\
\hline & Toplam & 725.152 & 334 & & & & & \\
\hline \multirow{3}{*}{$\begin{array}{l}\text { Su döngüsü } \\
\text { (5 madde) }\end{array}$} & Gruplar aras1 & 15.128 & 3 & 5.043 & \multirow[t]{3}{*}{3.090} & \multirow[t]{3}{*}{.060} & & \multirow[t]{3}{*}{ Yok } \\
\hline & Gruplar içi & 540.168 & 331 & 1.632 & & & & \\
\hline & Toplam & 555.296 & 334 & & & & & \\
\hline
\end{tabular}


Tablo 10'daki analiz sonuçlarına göre, sınıfların bilgi düzeyleri arasında test genelinde $\left[\mathrm{F}_{(3-331)}\right.$ $=9.245 ; \mathrm{p}<.05]$, çevre mühendisliği boyutunda $\left[\mathrm{F}_{(3-331)}=8.456 ; \mathrm{p}<.05\right]$ ve çevre kirliliği boyutunda $\left[\mathrm{F}_{(3-331)}=4.282 ; \mathrm{p}<.05\right]$ istatistiksel olarak anlamlı bir farklı1ık bulunmaktadır. Söz konusu farklılığın test genelinde ve çevre mühendisliği boyutunda, 5. sınıf öğrencileri ile 6. 7. ve 8. sinıf öğrencileri arasında olduğu; çevre kirliliği boyutunda ise 5. sınıf öğrencileri ile 6. ve 7. sınıf öğrencileri arasında olduğu belirlenmiştir. Tablo 9'daki ortalamalara göre 5. sınıf öğrencilerinin bilgi düzeyinin, diğer sınıflara göre daha düşük olduğu tespit edilmiştir. Su döngüsü boyutunda ise sınıfların bilgi düzeyleri arasında anlamlı bir farklılık bulunmadığı belirlenmiştir $\left[\mathrm{F}_{(3-331)}=3.090 ; \mathrm{p}>.05\right]$.

Tablo 10'daki eta kare $\left(\eta^{2}\right)$ değerlerine göre sinıf düzeyinin, test genelinde ve çevre mühendisliği boyutundaki bilgi düzeyine etkisinin orta büyüklükte olduğu, çevre kirliliği boyutundaki bilgi düzeyine etkisinin ise küçük büyüklükte olduğu bulunmuştur.

\section{Sonuç, Tartışma ve Öneriler}

Ortaokul öğrencilerinin çevre mühendisliği bilgi düzeylerini (ÇMBD) belirleyerek, öğrencilerin bilgi düzeylerini sınıf ve cinsiyet değişkenlerine göre karşılaştırmayı amaçlayan bu araştırma sonucunda, ortaokul öğrencilerinin çevre mühendisliğine ilişkin bilgilerinin orta düzeyde olduğu belirlenmiştir. Araştırmada kullanılan teste cevap vermeden önce, öğrencilerin çevre mühendisliğine yönelik bir uygulama yapmadıkları ve öğrencilere çevre mühendisliğine ilişkin bir bilgi verilmediği düşünüldügünde, bu bulgu beklenen bir sonuç olmakla birlikte sevindirici olduğu da ifade edilebilir. $\mathrm{Bu}$ bulgu ile benzer olarak 4 ila 8 . sınıf öğrencilerinin mühendislik bilgi düzeylerinin, farklı değişkenlere göre karşılaştırıldığ 1 bir araştırma sonucunda, öğrencilerin orta düzeyde mühendislik bilgisine sahip oldukları belirlenmiştir (Aydın, Saka ve Guzey, 2018).

Yapılan birçok araştırmada öğrencilerin mühendislikle ilgili bilgilerinin yetersiz olduğu sonucuna ulaşılmıştır. Çizimler, mülakat ya da ölçekler aracılığıyla elde edilen veriler neticesinde, öğrencilerin mühendisler tarafından yapılan faaliyetleri, tamirci, inşaat iş̧̧isi, teknisyen veya taşıt operatörlerinin yaptıkları faaliyetlerle karıştırdıkları belirlenmiştir (Bilen, Irkıçatal ve Ergin, 2014; Carr, Diefes-Dux ve Horstman, 2012; Cunningham, Lachapelle ve Lingren-Streicher, 2005; Fralick vd., 2009; Hirsch vd., 2011; Karatas, Micklos ve Bodner, 2011; Koyunlu Ünlü ve Dökme, 2017). Ayrıca öğrencilerin mühendislerin icat ve tasarım yaptıkları, hayatı kolaylaştırdıkları, işlerinde matematik kullandıkları gibi bilgilere sahip olmalarına rağmen, mühendislik alanının çeşitliliğine ilişkin yeterli bilgiye sahip olmadıkları belirlenmiştir (Çakmak, Bilen ve Taner, 2019). Bu araştırmada öğrencilerin çevre mühendisliğine ilişkin bilgilerinin orta düzeyde bulunmasında, kullanılan testin içeriğinde çevre mühendisliğine ilişkin soruların yanı sıra, çevre kirliliği ve su döngüsüne yönelik soruların da yer almasının etkili olabileceği düşünülmektedir. Araştırmada Türkçeye uyarlanarak geçerlik ve güvenirlik çalışmaları yapılan testin, çevre mühendisliğine yönelik bir fen, mühendislik ve girişimcilik uygulaması olan su filtresi tasarımına ilişkin sorular içermesinin, araştırmacı ve öğretmenlere kaynak olması açısından önemli olduğu ifade edilebilir.

Araştırmada öğrencilerin cinsiyetlerine göre çevre mühendisliğine ilişkin bilgi düzeyleri karşılaştırıldığında, kızlar lehine anlamlı bir fark olduğu belirlenmiştir. Ancak etki büyüklüğü değerine göre cinsiyetin bu fark üzerindeki etkisinin, küçük olduğu sonucuna ulaşılmıştır. Aydın, Saka ve Guzey, (2018) araştırmalarında, 6., 7. ve 8. sınıf öğrencilerinin mühendislik bilgi düzeylerinin kızlar lehine farklılık gösterdiği, 4. ve 5. sınıf öğrencilerinin mühendislik bilgi düzeylerinin ise cinsiyetlerine göre farklılık göstermediği sonucuna varmıştır. Öğrencilerin mühendislik uygulamalarına ilişkin bilgi düzeylerinin araştırıldığı başka bir çalı̧̧mada ise cinsiyet açısından bilgi düzeyinde anlamlı bir farklılık olmadığı bulunmuştur (Ozogul, Miller ve Reisslein, 2017). Sonuç olarak cinsiyetin, mühendislik bilgi düzeyi üzerindeki etkisini belirlemeye yönelik daha fazla araştırmaya ihtiyaç duyulduğu söylenebilir.

$\mathrm{Bu}$ araştırmada öğrencilerin ÇMBD’lerinde kızlar lehine küçük büyüklükte olmakla birlikte anlamlı farklılık bulunmasına rağmen, yapılan araştırmalarda erkek öğrencilerin mühendisliğe yönelik tutumlarının kız öğrencilere göre daha olumlu olduğu belirlenmiştir (Sadler, Sonnert, Hazari ve Tai, 
2012; Unfried, Faber ve Wiebe, 2014). Araştırmalarda ayrıca, kız öğrencilerin mühendislik kariyerine yönelme sürecinde, mühendislikle ilgili bilgi ve yeteneklerine erkeklere göre daha az güvendikleri belirlenmiştir (Besterfield-Sacre, Moreno, Shuman ve Atman, 2001; Ing, Aschbacher ve Tsai, 2014; Sadler vd., 2012). Bu bağlamda öğrencilerin mühendisliğe ilişkin bilgi düzeyleri ile mühendisliğe yönelik tutumları arasında bir ilişkinin olup olmadığının araştırılmasının önemli olduğu düşünülmektedir.

Ülkemizde STEM alanlarındaki yükseköğretim kurumlarında erkeklerin çoğunlukta olduğu, özellikle mühendislik kariyerine erkeklerin egemen olduğu belirtilmektedir (Korkut-Owen, Kelecioğlu ve Owen, 2014). Lise yıllarında kızların STEM alanlarına yönelik ilgilerinin, erkeklerin STEM alanlarına yönelik ilgilerine oranla daha hızlı azaldığı (Brotman ve Moore, 2008), lise yıllarında erkek öğrencilerde bir STEM kariyeri ile ilgilenme oranının sabit kaldığı, kız öğrencilerde ise bu oranın azaldığı belirlenmiştir (Sadler vd., 2012). Dolayısıyla öğrencilerin farklı mühendislik alanlarına yönelik bilgilerinin ve ilgilerinin erken yaşlarda belirlenmesinin önemli olduğu söylenebilir. Erken yaşlarda çevre mühendisliği ve farklı mühendislik alanlarına yönelik fen, mühendislik ve girişimcilik uygulamalarına yer verilerek, özellikle kız öğrencilerin mühendislik kariyerini tercih etme sürecinde özgüvenlerinin artırılabileceği düşünülmektedir.

Araştırmada öğrencilerin sınıflarına göre çevre mühendisliğine ilişkin bilgi düzeyleri karşılaştırıldığında, test genelinde 5. sınıf öğrencileri ile 6. 7. ve 8. sınıf öğrencileri arasında anlamlı bir farklılık olduğu belirlenmiştir. Eta kare $\left(\eta^{2}\right)$ değerine göre sınıf düzeyinin, bu farkın oluşmasındaki etkisinin orta büyüklükte olduğu bulunmuştur. Söz konusu farkın 5. sinıf öğrencilerinin bilgi düzeylerinin, diğer sınıflara göre daha düşük olmasından kaynaklandığı, sınıf düzeyi arttıkça ortalama bilgi puanının da arttığı belirlenmiştir. Bu bulgu, öğrencilerin sınıf düzeylerinin artmasıyla birlikte, bilişsel gelişim düzeylerinin, fen bilimlerine ilişkin bilgilerinin ve soyut düşünebilme yeteneklerinin de artması ile açıklanabilir. Literatürde bu bulgu ile örtüşen araştırma sonuçları bulunmaktadır; örneğin Aydın, Saka ve Guzey (2018) yaptıkları araştırmada 5. sınıf öğrencilerinin mühendislik bilgi düzeylerinin, 4. sınıf öğrencilerine kıyasla, 8. sınıf öğrencilerinin mühendislik bilgi düzeylerinin ise 6 . ve 7. sınıf öğrencilerine kıyasla daha fazla olduğunu belirlemiştir. Benzer olarak diğer bir araştırmada, daha büyük yaştaki ilkokul öğrencilerinin mühendislik uygulamalarına ilişkin bilgi düzeylerinin, daha küçük yaştaki öğrencilere göre daha fazla olduğu tespit edilmiştir (Ozogul, Miller ve Reisslein, 2017). Sonuç olarak öğrencilerin mühendislik kariyerine ilişkin ilgilerinin ve bilgilerinin geliştirilmesi açısından, anaokulundan itibaren her kademede fen, mühendislik ve girişimcilik uygulamalarına, okul ve okul dışı öğrenme ortamlarında yer verilmesinin gerekli olduğu düşünülmektedir.

Araştırmada ulaşılan sonuçlara dayanarak öğretmenlere yapılan öneriler şu şekildedir: Öğrencilerin çevre mühendisliği ve farklı mühendislik kariyerlerine yönelik bilgi edinebilmelerinde, bu kariyerlere yönelik tutum ve ilgileri oldukça önemlidir. Dolayısıyla STEM branşlarında görev yapan öğretmenlerin, sınıf ve sınıf dışında fen, mühendislik ve girişimcilik uygulamaları gerçekleştirmelerinin önemli olduğu söylenebilir. Bu araştırmada kullanılan ÇMBT'de ele alınan fen, mühendislik ve girişimcilik uygulaması, su filtresi tasarımıdır. Öğretmenler bu testi ön test olarak uygulayıp ardından öğrencilerine su filtresi tasarımını yaptırdıktan sonra son test olarak uygulayabilirler. Öğrencilerin çevre mühendisliğine yönelik bilgilerindeki değişimi belirlemek için testin yanı sıra çizimler ve mülakat yöntemi kullanılabilir. 2018 fen bilimleri dersi öğretim programındaki tüm ünitelerde, konuların özelliklerine göre, farklı mühendislik alanlarına yönelik fen, mühendislik ve girişimcilik uygulamaları gerçekleştirilebilir. Uygulamaların gerçekleştirilmesinde STEM branşlarındaki öğretmenlerin, uygulamanın içeriğine göre aralarında işbirliği yapmalarının etkili olacağı düşünülmektedir. Öğrencilerin takım çalışması, işbirliği ve iletişim gibi becerileri kazanmaları açısından uygulamaların işbirlikli gruplarda gerçekleştirilmesi tavsiye edilmektedir.

Araştırmadan ulaşılan sonuçlara dayanarak araştırmacılara yapılan öneriler şekildedir: $\mathrm{Bu}$ araştırma, Manisa ilinin Demirci ilçesindeki bir devlet ortaokulundaki 335 öğrenci ile sınırlıdır. Farklı 
bölgelerde, farklı okullarda, ilkokul öğrencileri de dâhil edilerek öğrencilerin çevre mühendisliği ve farklı mühendislik alanlarına ilişkin bilgileri belirlenebilir. Araştırmacılar, başarı testlerinin yanı sıra ölçeklerden, çizimlerden ve görüşme yönteminden de yararlanabilirler. Söz konusu ölçme araçları kullanılarak deneysel araştırmalar yapılabilir. Farklı fen, mühendislik ve girişimcilik uygulamalarının, farklı mühendislik alanlarına yönelik bilgi düzeyleri üzerindeki etkisi değerlendirilebilir. Öğrencilerin mühendislik kariyerine ilişkin bilgilerinin zaman içinde değişimi, daha uzun süreli boylamsal araştırmalarla incelenebilir. Cinsiyet ve sınıf düzeyi ile mühendisliğe yönelik bilgi düzeyi arasındaki ilişkinin daha ayrıntılı araştırılması gerektiği düşünülmektedir.

\section{Kaynakça}

Aydın, G., Saka, M., \& Guzey, S. (2018). 4-5-6-7. ve 8. sınıf öğrencileri için mühendislik bilgi düzeyi ölçeği. İlköğretim Online, 17(2). 750-768.

Balçın, M. D., \& Ergün, A. (2019). Altıncı sınıf öğrencilerinin gözünden havacılık ve uzay mühendisi. Pamukkale Üniversitesi Eğitim Fakültesi Dergisi, 45, 1-21, https://doi.org/10.9779/puje.2018.219.

Besterfield-Sacre, M. B.,Moreno, M., Shuman, L. J., \& Atman, C. J. (2001). Gender and ethnicity differences in freshman engineering student attitudes: A cross-institutional study. Journal of Engineering Education, 90(4), 477-490, https://doi.org/10.1002/j.2168-9830.2001.tb00629.x.

Bilen, K., Irkıçatal, Z., ve Ergin, S. (2014). Ortaokul öğrencilerinin bilim insanı ve mühendis algıları. XI. Ulusal Fen Bilimleri ve Matematik Eğitimi Kongresi Bildiri Özetleri Kitapçı̆̆ 11-14, Adana.

Boopathiraj, C., \& Chellamani, K. (2013). Analysis of test items on difficulty level and discrimination index in the test for research in education. International Journal of Social Science \& Interdisciplinary Research, 2(2), 189-193.

Brotman, J. S., \& Moore, F. M. (2008). Girls and science: A review of four themes in the science education literature. Journal of Research in Science Teaching, 45(9), 971-1002, https://doi.org/10.1002/tea.20241.

Büyüköztürk, Ş. (2018). Sosyal bilimler için veri analizi el kitabı (24. Bask1), Ankara: Pegem Akademi Yayınc1l1k, https://doi.org/10.14527/9789756802748.

Büyüköztürk, Ş., Kılıç Çakmak, E., Akgün, Ö. E., Karadeniz, Ş. ve Demirel, F. (2012). Bilimsel araştırma yöntemleri (13. Bask1). Ankara: Pegem Akademi Yayıncılık, https://doi.org/10.14527/9789944919289.

Bybee, R., W. (2014, February). Scientific literacy: Reflections on standards, stem, and stewardship. Paper presented at the Big Idea Seminar University of Nebraska, Lincoln. 24.07.2019 tarihinde https://bigideaseminars.unl.edu/pdf/Bybee.Nebraska_Scientific\%20Literacy_Reflections.pdf adresinden erişilmişsir.

Carr, R. L., Diefes-Dux, H. A., \& Horstman, B. (2012). Change in elementary student conceptions of engineering following an intervention as seen from the draw-an engineer test. Paper presented at the 2012 ASEE Annual Conference, San Antonio, Texas.

Creswell, J. W. (2008). Educational research: Planning, conducting and evaluating quantitative and qualitative research. New Jersey: Pearson.

Cunningham, C., M. (2009). Engineering is elementary. The Bridge, 30(3), 11-17. 24.07.2019 tarihinde https://www.eie.org/sites/default/files/research_article/research_file/2009-bridge_fall2009.pdf adresinden erişilmiştir. 
Cunningham, C. M., Lachapelle, C., \& Lindgren-Streicher, A. (2005). Assessing elementary school students' conceptions of engineering and technology. Proceedings of the American Society of Engineering Education Annual Conference, Portland, OR.

Çakmak, B., Bilen, K., \& Taner, M. S. (2019). Ortaokul öğrencilerinin mühendis ve mühendislik algıları. Anadolu Öğretmen Dergisi, 3(1), 32-43, https://doi.org/10.35346/aod.559599.

Daugherty, M. K. (2013). The prospect of an "A" in STEM education. Journal of STEM Education, 14 (2), 10-15.

EiE (Engineering is Elementary) (2018). Designing water filters instrument. 24.07.2018 tarihinde http://www.eie.org/sites/default/files/designing_water_filters_instrument.pdf adresinden erişilmiştir.

Ergün, A. (2018). Türk ortaokul öğrencilerinin mühendislik ve teknoloji algıları: Sınıf düzeyi ve cinsiyetin etkisi. Journal of Human Sciences, 15(4), 2657-2673, https://doi.org/10.14687/jhs.v15i4.5260.

Ergun, A., \& Balcin, M.D. (2019). The perception of engineers by middle school students through drawings. Eurasian Journal of Educational Research, 83, 1-28, https://doi.org/10.14689/ejer.2019.83.1.

Fralick, B., Kearn, J., Thompson, S., \& Lyons, J. (2009). How middle schoolers draw engineers and scientists. Journal of Science Education and Technology, 18(1), 60-73, https://doi.org/10.1007/s10956-008-9133-3.

Frehill, L.M. (1997). Education and occupational sex segregation: The decision to major in engineering. The Sociological Quarterly, 38(2), 225-249, https://doi.org/10.1111/j.15338525.1997.tb00475.x.

Gottfredson, L. S. (2002). Gottfredson's theory of circumscription, compromise and selfcreation. D. Brown \& Associates (Eds.). In Career choice and development (pp.101-106). Bensenville: Scholastic Testing Service.

Green, S. B., \& Salkind, N.J. (2005). Using SPSS for Windows and Macintosh: Analyzing and uunderstanding data (4th Edition) New Jersey: Pearson.

Gömleksiz, M. ve Erkan, S. (2010). Eğitimde ölçme ve değerlendirme (2. Bask1). Ankara: Nobel Yayın Dağıtım.

Gülhan, F., \& Şahin, F. (2018). A comparative investigation of middle school $5^{\text {th }}$ and $7^{\text {th }}$ grade students' of perceptions on engineers and scientists. Necatibey Faculty of Education Electronic Journal of Science \& Mathematics Education, 12(1), 309-338.

Hirsch, L. S., Berliner-Heyman, S., Kimmel, H., \& Carpinelli, J. (2011). Middle school students' perceptions of engineers before and after a summer enrichment program. In Proceedings of the International Conference for Engineering Education, https://doi.org/10.1109/fie.2011.6142990.

Ing, M., Aschbacher, P. R., \& Tsai, S. M. (2014). Gender differences in the consistency of middle school students' interest in engineering and science careers. Journal of Pre-College Engineering Education Research, 4(2), 1-10, https://doi.org/10.7771/2157-9288.1090.

Karatas, F. O., Micklos, A., \& Bodner, G. M. (2011). Sixth-grade students' views of the nature of engineering and images of engineers. Journal of Science Education and Technology, 20(2), 123-135, https://doi.org/10.1007/s10956-010-9239-2. 
Knight, M., \& Cunningham, C. (2004). Draw an engineer test (DAET): Development of a tool to investigate students' ideas about engineers and engineering. Paper presented at the 2004 Annual Conference, Salt Lake City, Utah.

Korkut-Owen, F., Kelecioglu, H., \& Owen, D. W. (2014). A decade of change gender trends in university enrollment: Implications for career counseling. International Journal of Human Sciences, 11(1), 794-813.

Koyunlu Ünlü, Z., \& Dökme, İ. (2017). Özel yetenekli öğrencilerin FeTeMM'in mühendisliği hakkındaki imajları. Trakya University Journal of Education Faculty, 7(1), 196-204.

Kubiszyn, T., \& Borich, G. (2003). Educational testing and measurement: Classroom application and practice (7th ed.). Hoboken, NJ: John Wiley\&Sons, Inc.

Lachapelle, C. P., Phadnis, P., Hertel, J., \& Cunningham, C. M. (2012). What is engineering? A survey of elementary students. Proceedings of the 2nd P-12 Engineeringand Design Education Research Summit, Washington, DC.

Lachapelle, C. P., \& Cunningham, C. M. (2007, March). Engineering is elementary: Children's changing understandings of science and engineering. In Proceedings of the ASEE Annual Conference \& Exposition.

Milli Eğitim Bakanlığı (MEB) (2018). Fen bilimleri dersi ögretim programı (ilkokul ve ortaokul 3, 4, $5,6, \quad 7$ ve 8 . sinuflar). Ankara. 05.05.2018 tarihinde http://mufredat.meb.gov.tr/ProgramDetay.aspx?PID=325 adresinden erişilmiştir.

Pearson, G. (2004). Collaboration conundrum. Journal of Technology Education 15(2), 66-76.

Sadler, P. M., Sonnert, G., Hazari, Z., \& Tai, R. (2012). Stability and volatility of STEM career interest in high school: A gender study, Science Education, 96(3), 411-427, https://doi.org/10.1002/sce.21007.

Tabachnick, B.G., \& Fidell, L.S. (2007). Using multivariate statistics. 5th ed. Boston: Allynand Bacon.

Tan, Ş. (2014). Öğretimde ölçme ve değerlendirme (10. Baskı). Ankara: Pegem Akademi Yayıncılık.

Topal, M. ve Arslan, E. I. (2010). Türkiye'de çevre mühendisliği bölümleri ve eğitimi. Erciyes Üniversitesi Fen Bilimleri Enstitüsü Dergisi, 26(1), 34-49.

Ozogul, G., Miller, C. F., \& Reisslein, M. (2017). Latinx and Caucasian elementary school children's knowledge of and interest in engineering activities. Journal of Pre-College Engineering Education Research (J-PEER), 7 (2), 15-26, https://doi.org/10.7771/2157-9288.1122.

Yıldırım, A. ve Şimşek, H. (2016). Sosyal bilimlerde nitel araştırma yöntemleri (10. Baskı). Ankara: Seçkin Yayıncılık. 


\section{Ek 1. ÇEVRE MÜHENDISSLİĞí BİLGİ TESTİ}

1. Sizce en doğru cevabı işaretleyin. Çevre mühendisleri...

A. Kamyon, uçak ve arabaları onarır.

B. Hava, toprak ve su problemlerini çözer.

C. Köprü, yol ve tünel tasarlar.

D. Cep telefonu, televizyon ve bilgisayar geliştirir.

2. Çevre mühendisleri aşağıdakilerden hangisini yapar?

A. Balinaların ne yediğini araştıır.

B. Sebze bahçelerini tasarlar.

C. Petrol sizıntılarını temizleme yolları arar.

C. Su arıtma sistemi

D. Bilgisayarla kontrol edilen tekneler

6. Toprak kirliliğini önlemek neden önemlidir?

A. Karada yaşayan canlıların ölmemesi için

B. İnsanların toprakta yetişen bitkileri yiyebilmesi için.

C. Kirli topraklar, suları kirletebileceği için.

D. Yukarıdakilerin hepsi.

7- 10 arasındaki soruları aşağıdaki şekle göre cevaplayınız.

D. Ağaçları kesmek için makine kullanır.

3. Sizce bir çevre mühendisi büyük bir olasıllkla aşağıdakilerden hangisini yapar?

A. Yeni tür yakitlar bulur.

B. Vahşi hayvanların bakımını yapar.

C. İnsan yapımı göl ve akarsular yapar.

D. Kara, su ve denizlere zarar verilmesini önler.

4. İş yerinde çevre mühendisi büyük bir olasilikla....
A. Toprak kirliliğini test eder
B. Tekneler için elektrik motorları tasarlar.
C. Hayvanlar için yeni yaşam alanları oluşturur.
D. Geri dönüşüm için cam, plastik ve kağıt toplar.

5. Bir çevre mühendisi büyük bir olasılıkla aşağıdakilerden hangisini tasarlar?

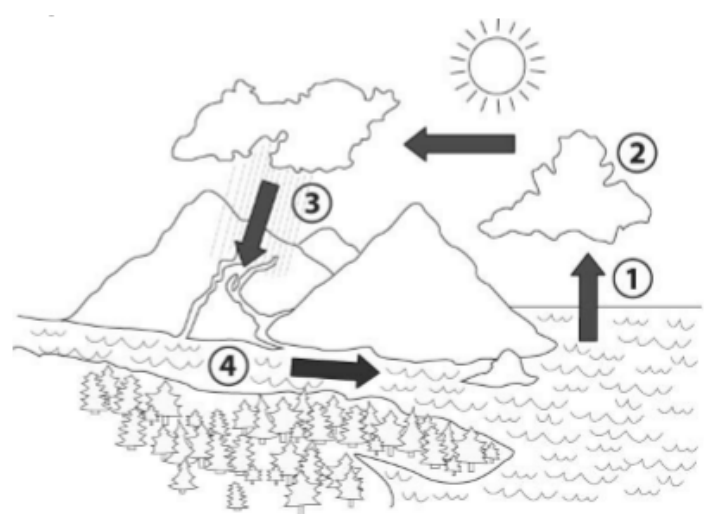

7. Şekil üzerinde 1 numarada gerçekleşen değişim nedir?
A. Su gazdan katıya dönüşüyor.
B. Su sıvıdan gaza dönüşüyor.
C. Su katıdan sıvıya dönüşüyor.
D. Su sıvıdan katıya dönüşüyor.

8. Şekilde buharlaşma kaç numarada gerçekleşir?
A. 1
B. 2
C. 3
D. 4

A. Hayvanat bahçesi

B. Bahçe 
9. Şekilde yoğunlaşma (yoğuşma) kaç numarada gerçekleşir?
A. 1
B. 2
C. 3
D. 4

10. Şekilde yağmur kaç numarada oluşur?
A. 1
B. 2
C. 3
D. 4

11. İçerisinde yapraklar bulunan kirli bir sudaki yaprakları, sudan ayırma işini aşağıdaki filtrelerden hangisi en iyi yapar?
A. Kum
B. Kağıt
C. Pamuk topları
D. Metal bir elek

12. Aşağıdakilerden hangisi su kirliliğine neden olabilir?
A. Çiftlik hayvanlarının dışkısı
B. Hasarlı makinalardan dökülen/sızan petrol
C. İnsanlar tarafindan yapılan gübreleme
D. Yukarıdakilerin hepsi

13. Bir çevre mühendisi işinde aşağıdakilerden hangisini düşünüyor olabilir?
A. Doğayı nasıl koruyacağını
B. Kirliliği nasıl önleyebileceğini
C. İçme suyunun nasıl arıtılacağını
D. Yukarıdakilerin hepsini

14. Aşağıdakilerden hangisi bir çevre mühendisinin büyük bir olasılıkla yapmayacağ 1 işlerden birisidir?
A. Kirliliği gidermek için teknolojik tasarımlar yapmak
B. Toprak kirliliğinin kaynağını bulmak
C. Kirliliği gideren bir makineyi çalıştırmak ve onarmak
D. Bir köy halkına nehir kirliliği sorununu çözme konusunda yardımcı olmak

15. Kirlenmiş bir göl suyundan hangi canlılar etkilenir?
A. Göl çevresindeki bitkiler
B. Gölde yaşayan balıklar
C. Göl yakınında yaşayan insanlar
D. Yukarıdakilerin hepsi

16. Toprak kirliliğini aşağıdakilerden hangisi arttırır?
A. Fabrikalar
B. Otoparklar
C. Çiftlik hayvanları
D. Yukarıdakilerin hepsi

17. Aşağıdakilerden hangisi suları kirletebilir?
A. Köpekler
B. Kuşlar
C. Tekneler
D. Yukarıdakilerin hepsi

Ahmet metal bir elek kullanarak su filtresi yapar. Ahmet yaptığ 1 filtre ile içerisinde küçük parçacıklar olan kahverengi suyu arıtmak ister. Ahmet kirli suyu filtreye döker ancak suda hiç bir değişim olmadığını görür. 
18. Ahmet sudaki küçük parçacıkları arıtmak için aşağıdakilerden hangisini yaparsa en iyi sonucu alır?

A. Parçacıkları kaşık yoluyla sudan almak

B. Daha büyük delikli bir filtre malzemesi kullanmak

C. Daha küçük delikli bir filtre malzemesi kullanmak

D. Küçük parçacıkları ayırmak mümkün değildir

19. Ahmet sudaki kahverengiliği gidermek için aşağıdakilerden hangisini yapmalıdır?

A. Suyu sabunla temizlemek

B. Daha yumuşak bir filtre kullanmak

C. Daha küçük delikli bir filtre kullanmak

D. Kahverengiliği gidermek mümkün değildir 
20. Aşağıdakilerden hangisi su döngüsündeki olayların en doğru sıralanışıdır? (Toplanma suyun yeryüzünde birikmesi anlamındadır).
A. toplanma buharlaşma yağış yoğunlaşma döngü baştan başlar
B. yoğunlaşma buharlaşma yağış toplanma döngü yeniden başlar
C. yağı̧̧ toplanma buharlaşma yoğunlaşma döngü yeniden başlar
D. buharlaşma yağış toplanma yoğunlaşma döngü yeniden başlar

\section{Ek 2. ÇEVRE MÜHENDİSLİĞİ BİLGi TESTİ BELİRTKE TABLOSU}

\begin{tabular}{|c|c|c|c|}
\hline Ünite/Konu & Kazanımlar & Kavramlar & Soru \\
\hline \multirow[t]{2}{*}{ İnsan ve Çevre } & $\begin{array}{l}\text { İnsan ve çevre arasındaki etkileşimin önemini } \\
\text { ifade eder. } \\
\text { Yakın çevresindeki veya ülkemizdeki bir çevre } \\
\text { sorununun çözümüne ilişkin öneriler sunar. } \\
\text { Günlük hayattan bir problemi tanımlar. } \\
\text { Problem için muhtemel çözümler üretir ve } \\
\text { bunları karşılaştırarak ölçütler kapsamında } \\
\text { uygun olanı seçer. } \\
\text { Ürünü tasarlar ve sunar. }\end{array}$ & $\begin{array}{l}\text { Çevreyi koruma ve } \\
\text { güzelleştirme, insan- } \\
\text { çevre etkileşimi (insanın } \\
\text { çevreye etkisi), yerel ve } \\
\text { küresel çevre sorunları }\end{array}$ & $\begin{array}{l}1,2,3,4,5 \\
11,13,14 \\
18,19\end{array}$ \\
\hline & $\begin{array}{l}\text { İnsan faaliyetleri sonucunda gelecekte } \\
\text { oluşabilecek çevre sorunlarına yönelik } \\
\text { çlkarımda bulunur. } \\
\text { İnsan-çevre etkileşiminde yarar ve zarar } \\
\text { durumlarını örnekler üzerinde tartışır. }\end{array}$ & $\begin{array}{l}\text { Çevre kirliliği, insan- } \\
\text { çevre etkileşimi, yerel ve } \\
\text { küresel çevre sorunları }\end{array}$ & $\begin{array}{lll}6, & 12, & 15 \\
16, & 17\end{array}$ \\
\hline $\begin{array}{l}\text { Madde } \\
\text { Döngüleri ve } \\
\text { Çevre } \\
\text { Sorunları }\end{array}$ & $\begin{array}{l}\text { Madde döngülerini şema üzerinde göstererek } \\
\text { açılar. } \\
\text { Madde döngülerinin yaşam açısından önemini } \\
\text { sorgular. }\end{array}$ & Su döngüsü & $\begin{array}{l}7,8,9,10, \\
20\end{array}$ \\
\hline
\end{tabular}




\section{Ek 3. ETIKK KURUL BELGESI}

Evrak Tarih ve Sayıs1: 28/03/2018-E.27968

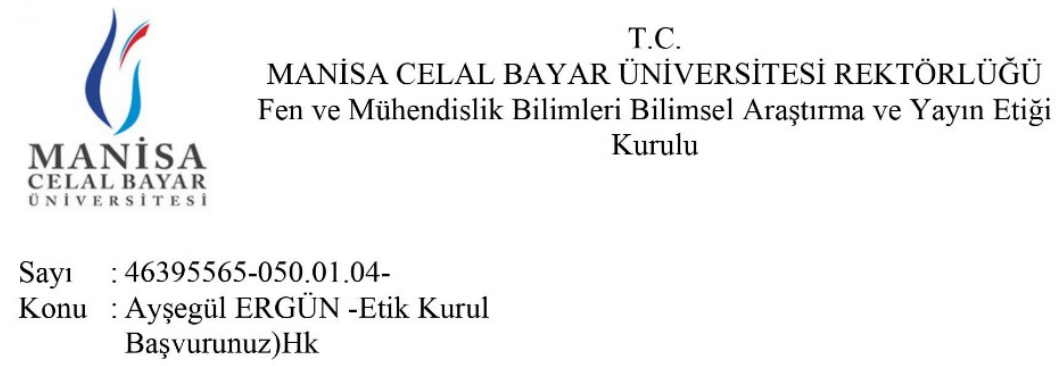

Sayın Dr. Öğr. Üye. Dr. Ayşegül ERGÜN

İlgi : 07/02/2018 tarihli ve 7715 sayılı yazı.

Tasarım Temelli Fen Eğitiminde, Fen Teknoloji, Mühendislik ve Matematik Uygulamaları: Beşinci Sınıf İnsan ve Çevre Ünitesi Örneği adlı"konulu başvurunuz Fen ve Mühendislik Bilimleri Bilimsel Araştırma ve Yayın Etik Kurulu'nun 07.03.2018 tarih ve 2018/02 sayılı toplantısında görüșülmüș olup, araștırmanın etik yönden uygunluğuna karar verilmiștir.

Kurulumuzda alınan karar ekte gönderilmektedir.

Bilgilerinizi rica ederim

e-imzalıdır

Prof. Dr. Ahmet ATAC

Kurul Başkanı

Ek: 1-Nolu Karar (1 sayfa)

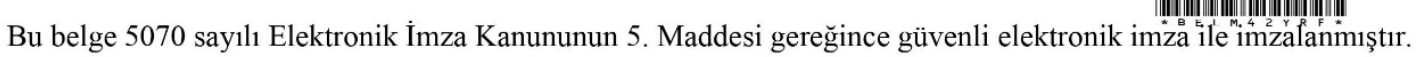


T.C.

MANISA CELAL BAYAR ÜNIVERSITESI REKTÖRLÜĞÜ FEN VE MÜHENDÍSLIK BİLIMLERİ BİLIMSEL ARASTIRMA VE YAYIN ETIKK KURULU KARARLARI

\begin{tabular}{|l|l|}
\hline Toplantı Tarih & $: 07.03 .2018$ \\
Toplantı Sayısı & $: 2018 / 02$ \\
Toplantıda Alınan & $: 3$ \\
Karar Sayısı & \\
\hline
\end{tabular}

Fen ve Mühendislik Bilimleri Bilimsel Araştırma ve Yayın Etik Kurulu 07.03.2018 tarih ve saat 16:00'da Rektörlük Yönetim Kurulu Toplantı odasında toplanmış, aşağıdaki kararlar alınmıştır.

\section{KARAR:}

1- Üniversitemiz Eğitim Fakültesi Öğretim Üyesi Yrd.Doç.Dr. Ayșegül ERGÜN'ün 07.02.2018 tarih ve E.7715 nolu Fen ve Mühendislik Bilimleri Bilimsel Araştırma ve Yayın Etik Kurulu'na "Tasarım Temelli Fen Eğitiminde, Fen Teknoloji, Mühendislik ve Matematik Uygulamaları: Beşinci Sınıf İnsan ve Çevre Ünitesi Örneği adı»” konulu bașvurusunun Etik yönden uygunluğuna,

\section{Toplantıya katılan üyelerin oy birliği ile karar verildi.}

(e-imzalıdır)

Prof.Dr-Mustafa OSKAY

(Bașkan Yardımcısı)

(üye)

(Katılmadı)

(e-imzalıdır)

Prof.Dr.Ahmet TƯRK

Üye (e-imzalıdır)

Prof.Dr.Ahmet ATAÇ

Başkan

(e-imzalıdır)

Yüksel ABALI

Üye

(e-imzalıdır)

Prof.Dr.Altay Uğur GŬL

Üye 